\title{
Correction to: HIV-1 IN/Pol recruits LEDGF/ p75 into viral particles
}

Belete Ayele Desimmie ${ }^{1,6+}$, Caroline Weydert ${ }^{1 \dagger}$, Rik Schrijvers $^{1}$, Sofie Vets ${ }^{1}$, Jonas Demeulemeester ${ }^{1}$, Paul Proost ${ }^{2}$, Igor Paron ${ }^{3}$, Jan De Rijck ${ }^{1}$, Jan Mast ${ }^{4}$, Norbert Bannert ${ }^{5}$, Rik Gijsbers ${ }^{1}$, Frauke Christ ${ }^{1}$ and Zeger Debyser ${ }^{*}$

\section{Correction to: Retrovirology 12:16 (2015)}

https://doi.org/10.1186/s12977-014-0134-4

Following publication of their article [1], the authors realized that honest splices in two figures were not indicated. These splices do not affect in any case the results but ought to have mentioned in the legend or indicated by white separators in the figure.
In Fig. 1c, Fractions 4-11 were run on a different gel than 1-3 because of limited slots per gel. The representation (empty lanes) does not affect the result.

In Fig. 4c we left out the MW marker but did not indicate the splice. Again, this representation did not affect the results.

Therefore, the authors would like to replace Figs. 1c and $4 \mathrm{c}$ with new ones, and update legends accordingly with the changes marked in bold.
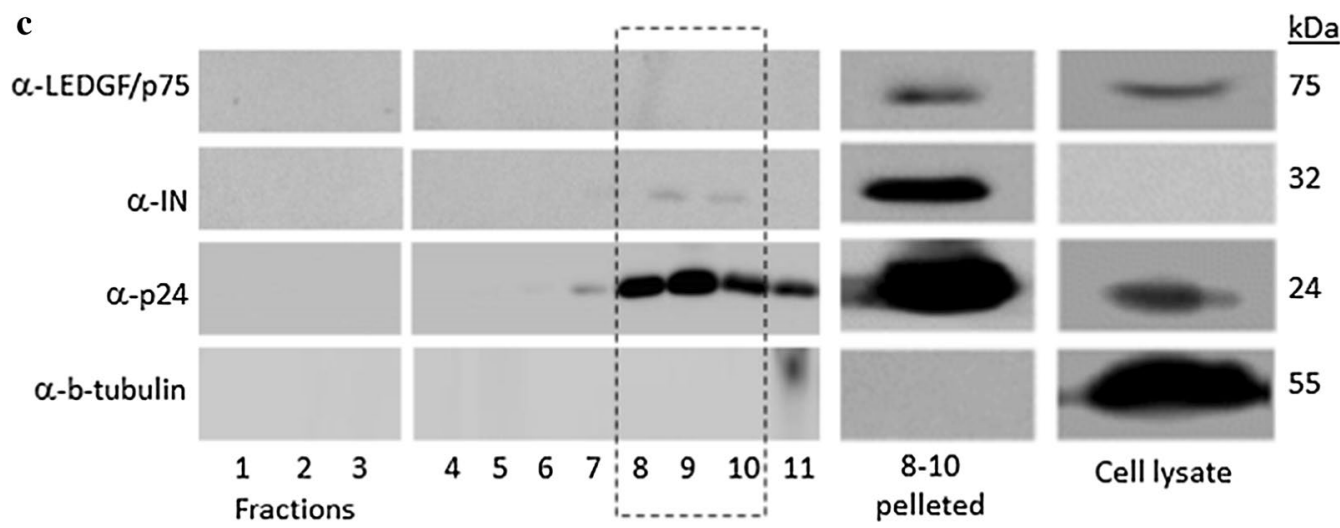

Fig. 1 c Western blot analysis of individual fractions, pooled fractions 8-10 (delineated with a broken line) and producer cell lysate

The original article can be found online at https://doi.org/10.1186/s1297

7-014-0134-4.

${ }^{*}$ Correspondence: zeger.debyser@med.kuleuven.be

${ }^{\dagger}$ Belete Ayele Desimmie and Caroline Weydert contributed equally to this

work

1 Department of Pharmaceutical and Pharmacological Sciences, KU

Leuven, Laboratory for Molecular Virology and Gene Therapy, Louvain,

Flanders, Belgium

Full list of author information is available at the end of the article

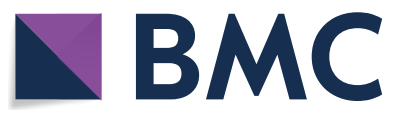

(c) The Author(s) 2020. This article is licensed under a Creative Commons Attribution 4.0 International License, which permits use, sharing, adaptation, distribution and reproduction in any medium or format, as long as you give appropriate credit to the original author(s) and the source, provide a link to the Creative Commons licence, and indicate if changes were made. The images or other third party material in this article are included in the article's Creative Commons licence, unless indicated otherwise in a credit line to the material. If material is not included in the article's Creative Commons licence and your intended use is not permitted by statutory regulation or exceeds the permitted use, you will need to obtain permission directly from the copyright holder. To view a copy of this licence, visit http://creativecommons.org/licenses/by/4.0/. The Creative Commons Public Domain Dedication waiver (http://creativecommons.org/publicdomain/zero/1.0/) applies to the data made available in this article, unless otherwise stated in a credit line to the data. 


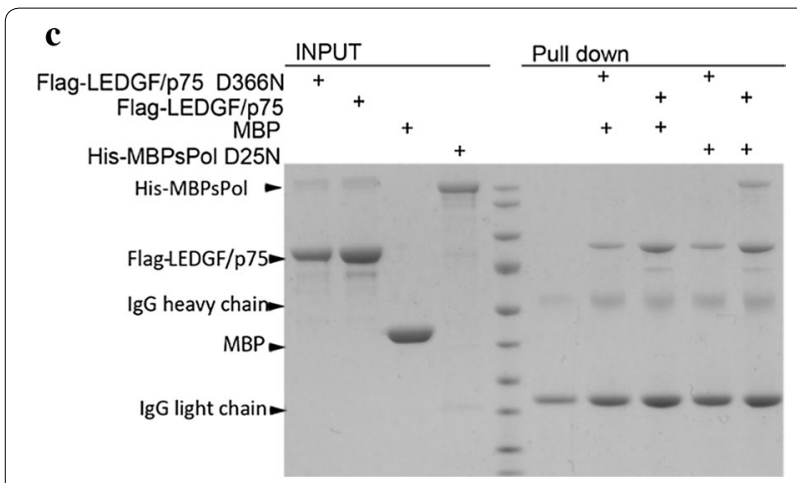

Fig. 4 c Pull-down of His-MBP-SPol_PR $R_{D 25 N}$ using recombinant Flag-LEDGF/p75 WT $_{\text {or Flag-LEDGF/p75 }}$ D366N. A MW marker was run in between input and pull-down lanes and Agrochemical Research Centre CODA-CERVA, Brussels, Belgium. ${ }^{5}$ Robert Koch Institute, Centre for HIV and Retrovirology, Berlin, Germany. ${ }^{6}$ Present Address: Viral Mutation Section, HIV Drug Resistance Program, Center for Cancer Research, National Cancer Institute, Frederick, MD, USA.

Published online: 29 July 2020

\section{Reference}

1. Desimmie BA, Weydert C, Schrijvers R, Vets S, Demeulemeester J, Proost P, Paron I, De Rijck J, Mast J, Bannert N, Gijsbers R, Christ F, Debyser Z. HIV-1 IN/Pol recruits LEDGF/p75 into viral particles. Retrovirology. 2015;12:16. https://doi.org/10.1186/s12977-014-0134-4.

\section{Publisher's Note}

Springer Nature remains neutral with regard to jurisdictional claims in published maps and institutional affiliations.

\section{Author details}

1 Department of Pharmaceutical and Pharmacological Sciences, KU Leuven, Laboratory for Molecular Virology and Gene Therapy, Louvain, Flanders, Belgium. ${ }^{2}$ KU Leuven, Laboratory of Molecular Immunology, Rega Institute, Louvain, Flanders, Belgium. ${ }^{3}$ Department of Proteomics and Signal Transduction, Max-Planck Institute of Biochemistry, 82152 Martinsried, Germany. ${ }^{4}$ Veterinary 